\title{
A detailed analysis of evolution of water rights in South Africa: An account of three and a half centuries from 1652 AD to present ${ }^{\#}$
}

\author{
DD Tewari* \\ School of Economics and Finance, University of KwaZulu-Natal, Westville Campus, Durban 4001, South Africa
}

\begin{abstract}
This study reviews the changing scene of water rights in South Africa over the last three and a half centuries and concludes that they have come full circle, with some modifications, since the invoking of Dutch rule in the Cape in $1652 \mathrm{AD}$ The study stipulates that adoption of a modern rights structure is a welcome change and a progressive step taken by the democratic government; however, its success depends to a great extent on the institutional efficiency of the state which performs the role of trustee or custodian of the water resource. The responsibilities of trusteeship with respect to managing water rights or permits are met through a decentralised decision-making system. The management of water rights/permits thus depends on the administrative and judicial efficiency of organisations and government departments. Therein lurks the danger of corruption, bureaucratic inefficiency, and insecurity of permits, and hence enough potential to stifle the long-term incentives to invest in the water sector.
\end{abstract}

Keywords: water rights, riparian, dominus fluminis, appropriation, modern water rights, sustainability, South Africa

\section{Introduction and objectives}

The availability of water in the South African context has more or less remain unchanged as it depends on climatic factors which have not changed, at least within the last 10000 years (DWAF, 1986). The current research on climate change confirms that it has the potential to impact very significantly on both the availability of and requirements for water in South Africa (DWAF, 2004, p.50). The average annual rainfall in South Africa is about $450 \mathrm{~mm} / \mathrm{yr}$, well below the world average of about $860 \mathrm{~mm} / \mathrm{yr}$, and this rain falls mostly on the east coast with very little in the interior parts (DWAF, 2004 p.50). Water consumption in the country is growing rapidly as industrialisation and urbanisation surges ahead. Since demand is exceeding the supply, South Africa is now being classified as one of Africa's water-stressed countries (DWAF, 2004 p.15). The evolution of water laws and consequent development/ change in the nature and structure of water rights in South Africa is intricately related to the increasing demand for water and political scenes that have unfolded in the country over the last three and a half centuries. The worldwide movements for environmental and human rights have also precipitated various reforms in the last decade of the $20^{\text {th }}$ century, affecting water laws and rights in various countries. Historically speaking, the development of water laws in South Africa is woven with fabric of both economic and political colours and should be understood within the context of conquest and colonisation. As the

\# Revised version. Paper originally presented at the International Water History Association (IWHA) $2^{\text {nd }}$ Conference, 10-12 August 2001, University of Bergen, Norway, and published as a chapter by Tewari DD (2005) An Evolutionary History of Water Rights in South Africa, Water World, IWHA. 157-182.

* To whom all correspondence should be addressed.

푱 +2731 2608046; fax: +2731 2608339;

e-mail: devitewari@yahoo.com or Tewari@ukzn.ac.za

Received 18 December 2008; accepted in revised form 9 September 2009. country changed hands from the Dutch to the British and then to the Afrikaners, and very recently to a democratic government representing all ethnic groups in the country, so did the water laws and emanating water rights (Tewari, 2005).

Knowledge of the changing nature of water laws and associated rights can enhance the understanding of policyand law-makers in South Africa and elsewhere, especially in other countries of sub-Saharan Africa as these countries have arid climates and their water problems are of similar nature. An understanding of the issues of water rights under arid or semi-arid conditions as distilled from this analysis can also be useful to lawmakers in other arid parts of the world. The study conduces a comprehensive understanding of evolution or transformation of water rights during 350 years in South Africa and enlightens how the changing legal philosophy of the ruling class has produced a different sets of water rights over the years. The evolution of water rights is thus discussed within 4 broad periods:

- The pre-colonial period under African customary rule

- Dutch East India Company (Vereenigde Oost Indiese Companje, VOC) rule spanning from 1652 to the $1^{\text {st }}$ decade of the $19^{\text {th }}$ century (1810)

- The colonial period under British control followed by apartheid rule by Afrikaner nationalists from about 1810 to 1990

- Democratic (modern) rule from 1991 to the present.

The major purpose of the study is to highlight the water management issues and social and economic forces that drove the development of different water rights in the country as it moved forward from medieval to modern times. More specifically, the study focuses on the modern water rights regime that has been developed under the democratic government. The intent is to examine how the modern rights will fare and what sort of constraints can stifle the materialisation of their full impacts.

The material of this study is thus organised into 8 sections. The $2^{\text {nd }}$ section delineates a brief overview of doctrines of 
water rights in general. The next sections deal with the evolution of water rights under, respectively, African customary law, Dutch, British, and Afrikaner nationalist laws. Finally, modern water rights under the current democratic rule are discussed. Conclusions and major lessons garnered from this study are discussed in the last section.

\section{A brief overview of prevailing water rights doctrines}

The need to regulate and control the supply of, and demand for, water by policy measures is necessitated by the need to supply the resource on sustainable basis to all users. One of the important factors in allocating or creating water rights is the climate. Even cultural advancement is considerably influenced by climatic conditions. Hall argued that:

'Climatic and geographical conditions are therefore of the greatest importance when questions of water rights come to be considered. If there is a scarcity of water the efforts of the community will be directed towards conserving the water and those of the individual to obtaining as much of it as he can for himself. If there is a superfluity of it the inhabitants will be occupied with efforts to get rid of it by drainage and canalisation, and they will make strenuous efforts to add to their land by reclaiming new areas from inundation (Hall, 1939 p.7)'.

The objective of granting water rights is thus ultimately related to improving the water management on the land and also to using the scarce water resource on a sustainable basis. Supplying water on a sustainable basis refers to the ability to provide for all water needs, whether they are social, economic, environmental, physical, biological, or religious, of the current generations without jeopardising the needs of future generations. The sustainable supply of water to all users is an immense task complicated by hydrological, logistical, economical, sociological, organisational, technical and environmental as well as political issues (DWAF, 1986 p. 1.1).

Apart from climate, the variation in water uses and hydrological conditions across the country also influences the allocation of water rights in a country. For example, the distribution of South African river systems is concentrated in a few provinces such as Mpumalanga, Kwazulu-Natal, and the Cape, while the rest of the country is dry. The uneven distribution of water thus engenders water scarcity which in turn induces more stringent rules for water use.

It can be said, therefore, that climatic conditions, hydrology and water uses are among the important factors in the evolution of water rights in a country. Among other factors, sociocultural contexts are important determinants of water rights. For example, the environmental and human right to water use has become very important in the last half of the $20^{\text {th }}$ century across the world. There are 4 important legal doctrines that define the terms and conditions of water use, derived from a combination of cultural and environmental factors: dominus fluminis, riparian, appropriation, and correlative (Black and Fisher, 2001 pp. 39-91).

The dominus fluminis or absolute ownership principle requires complete control of the resource by the governing party. This doctrine prevailed under Dutch rule in South Africa. In the United States it was used by some eastern states in the abstraction of groundwater. Under the riparian doctrine, the right to the use of water resides in the ownership of riparian lands - property that borders the water body. The doctrine has been modified to make it amenable to local conditions by various countries. Riparian rights cannot be transferred for the use of non-riparian land nor can they be lost by non-use. The riparian doctrine was derived from the English common law, which was borrowed in part from Roman civil law. In the eastern United States, the riparian doctrine was commonly used. British rulers in South Africa also adopted this doctrine.

As per the appropriation or Colorado doctrine, the rights to use water are given to those who claim it first; popularly known as the 'first in time is first in right' principle. The prior appropriation system is not affected by the ownership of the land and the appropriative rights can be lost through abandonment, unlike riparian rights. This doctrine was used in the western United States but was not opted for by South African rulers.

The correlative rights doctrine (also called California doctrine) combines certain elements of both riparian and appropriation doctrines and is commonly applied to groundwater. This requires that owners of the overlying land own the common aquifer or groundwater basin as joint tenants and each is allowed a reasonable amount for his own use. In the last quarter of the $20^{\text {th }}$ century, the gradual convergence of riparianism and prior appropriation doctrines has taken place in the United States of America - thus accepting the importance of water regulation (Thompson, 2006 p. 142). For example, originally riparian law was based on the natural flow doctrine which effectively prohibited diversion of water from streams. This worked well in the pre-industrial society. As industrialisation proceeded, demand for water as a source of power for mills increased, and led to the development of the reasonable use doctrine which allowed for some diversions (Thompson, 2006 p. 144). Under all doctrines, water rights are, however, usufructuary which means that a person obtains the right to use but not own the water body (Black and Fisher, 2001 pp. 39-91).

In the South African context, the first 2 doctrines - dominus fluminis and riparian - were used. For example, the Dutch rulers since 1652 adopted the principle of res omnium communes to impose control over the streams of Table Bay Valley, and control was exercised through a series of placcaets. The Company treated water as a public commodity. This was later replaced by a system where the state was dominus fluminis (Uys, 1996 p.190). Under the British rule, water was considered a private commodity and the riparian principle was adopted. Thus, water rights decisions in the court favoured individuals. However, later the apartheid regime under Afrikaner rule swung the balance in favour of the Roman-Dutch law.

The current democratic regime sought to find a balance between riparian and dominus fluminis principles and introduced the modern rights regime. Water is hence treated as a semi-public and semi-private commodity and the state adopted the dual economy model to engender economic development (Tewari, 2008; Temple, 2005). These themes are followed in this study and examples and court cases are supplied to demonstrate the political and vested interests that existed in the development of a certain kind of water rights. It is also for these reasons that the periodisation in water rights evolution tends to closely follow that of the political history of the country, as the 2 are inalienably linked.

\section{Water rights under African customary rule (pre-colonial era)}

Prior to colonisation of South Africa, African customary law governed water rights in the pre-colonial society. The water rights were then just common knowledge, were not contested among individuals in the community, and only came up when a community or a tribe felt that another tribe or community was 
unfairly encroaching onto its resources to its disadvantage. The Bantu people of Southern Africa had a subsistence economy based on hunting of animals and gathering of food. The San in particular were hunter-gatherers while the Khoikhoi were stock farmers (Davis, 1989 p.10). In these communities water like land was free, but land tenure was controlled by the chief and private ownership was not permitted. For quite some time the settler colonising community did not interfere with African communities and they were allowed to run as separate entities and follow their trade/business. This resulted in the dual system of land ownership and as a result a dual system of water rights (Burman, 1973 p. 412). With the passage of time, the colonial community established and aligned itself increasingly in commercial terms with the natives, and the native community, which was subsistence-inclined, continued to enjoy the ownership of resources based on the chief's control without individual tenure (Bennet, 1995 p.133). The encroachment of native resources by settlers finally resulted in the subjugation of African communities. As a result, many Khoikhoi farmers were forced to work on Dutch East India Company farms, as they lost access to land and water (Guelke and Shell, $1992 \mathrm{p}$. 811). The colonial government also did not take particular interest in creating a uniform policy for native communities. That is why the water rights for the greater part of the history of South Africa generally refer to access to water and water use by the colonists, Dutch, British, and Afrikaners. The history of water rights in South Africa is ence largely the history of the ruling class. For example, the colonial governments formed rules/ laws in their own business interests and as a result the majority African population was sidelined. Only after installation of a democratic government in the 1990s, were water rights universalised and imparted to all citizens without any prejudice of race and ethnicity. However, some attempts were made to develop minor irrigation in homelands before 1950 but they did not go very far in bringing a change in the lives of African people (Tlou et al, 2006 p. 28).

\section{Water rights under Dutch rule}

The arrival of the Dutch and their decision to settle at the Cape of Good Hope in 1652, led by Jan van Riebeeck, invoked the application of Roman-Dutch law in the new society. The Roman water law was a primitive system and was used to regulate the legal relationships within the farming community along the Tiber River in the Roman Empire about 2000 years ago. The Roman law recognises 3 classes of water rights: private, common, and public. The private water is owned by individuals and the individual has the right to use it. The common water refers to the water which everyone has the right to use without limit and permission. The public water is owned by the state and is subject to state control.

In the Roman law, things like the air, the deep sea and running water were termed res omnium communes (Wiel, $1909 \mathrm{p}$. 191). The running water in a natural stream was not owned by anyone, but once taken from the stream became private property during the period of possession (Wiel, 1909 p.213). The common law of England applied the Roman concept that water was 'res communis' and could not be the object of ownership, not even by the state or crown, but was owned by all or was res communis omnium (Caponera, 1998). The law of res omnium communes thus became a guiding principle in The Netherlands and later in South Africa. The Roman law gradually got accepted into the laws of The Netherlands between the $14^{\text {th }}$ and $16^{\text {th }}$ centuries, and produced a kind of hybrid law, known as Roman-Dutch law. This law made the distinction between public and private use of water. Public water was the one which had potential for communal use, while private water was for the individual personal use. The state was given the overall right to control the use of public water. The evolution of water rights in South Africa was highly influenced by legal developments in The Netherlands as, in the latter half of the $17^{\text {th }}$ century and the whole of the $18^{\text {th }}$ century, the Cape of Good Hope was a Dutch colony subject to ultimate control from The Netherlands. The Dutch rulers chose to apply the laws of The Netherlands: the doctrine of state ownership of all public rivers was accepted in the $17^{\text {th }}$ century.

The key writers of $17^{\text {th }}$ century water rights, which became the main source of authority in South Africa, include Grotius, Groenewegen, Vinnius, Van Leeuwen and Johannes Voet. These writers wrote extensively on Dutch laws in The Netherlands and their writings became major milestones in carving out Dutch legal history. Later when the Dutch East India Company (VOC) colonised the Cape, the Dutch legal principles were applied in South Africa (Uys, 1996 pp. 175178). Grotius advocated that the rivers, lakes, and beds and banks of steams belong to the whole community. Vinnius and Groenewegen argued that all rivers were royal possessions and ownership of these was vested in people. Voet also incorporated into his commentaries the rules laid down in the Digest for control of the use of public streams in the Roman State (Hall. 1939 pp. 8-9).

The establishment of Dutch control of water resources in the Table Bay Valley and its outskirts was not swift, but rather came in 2 phases or periods. The $1^{\text {st }}$ period dated from 1655 to 1740 , when a series of placcaets was issued to control the use of streams of Table Bay Valley. The $2^{\text {nd }}$ period or phase was from 1760 to 1827, when the colonial government resorted to the granting of entitlements from streams and this became the major tool for resolving water conflicts between water users. In the $1^{\text {st }}$ phase the colonist took control of the streams of the Table Bay Valley and in the $2^{\text {nd }}$ phase they declared their dominus fluminis status as their 'expansion of sphere of influence' broadened (Thompson, 2006 p. 35).

At the end of the first 3 years of settlement (i.e. by 1655), Van Riebeeck came under pressure to control water use and activities in the Valley for hygienic reasons. A contingent of the Dutch East India Company's merchantmen became ill as a result of impurities in the drinking water obtained from the streams of Table Bay Valley. The burghers (settlers) upstream were using the river water for bathing and washing their personal belongings, which affected the health of downstream users who depended on the same stream for drinking water. Van Riebeeck issued a placcaet on 10 April 1655 that prohibited the washing of persons and personal belongings in the stream (Thompson, 2006 p. 34). The General Proclamation or placcaet prohibiting upstream water pollution was repeated in 1657. Between 1652 and 1740 a series of placcaets was issued to control the quantitative and qualitative use of the streams of the Table Bay Valley (Thompson, 2006 p.35). When this pollution did not stop immediately, penalties were imposed on would-be offenders. The Company thus took the position that it had the right to control the use of running streams in the colony.

In the decade subsequent to 1652 , about 120 burghers had settled in the Cape and gardens mushroomed, starting at Table Bay. Some settlers moved into the interior (later to be referred to as Trek-Boers) and became pastoralists. It soon became clear to these settlers and the Company that South Africa, unlike 
The Netherlands, was a water-scarce country, with limited river water available, relatively low rainfall and prone to droughts. In 1661, the Company began to control water use for irrigation by burghers on piecemeal basis. A placcaet was issued on 16 December 1661, forbidding the use of water for irrigation in order to allow the Company's corn-mill to function (Thompson, 2006 p.34; Hall, 1947 p.1). The limited availability of water for the Boer pastoralists also led to the introduction of the merino breed of sheep from Spain (Davis, 1989 p.21). As a result of rising water demand from the mushrooming gardens and also the Company mills, there was constant friction among the garden owners, between themselves and also against the Company miller. These conflicts were managed through a system of granting entitlements by the Company. The entitlements were regulated by granting turns of water use, referred to as 'besondere gunsti' (Thomspson, 2006 p.35). The Company then agreed with upstream farmers on a system of turns of irrigation so that the functioning of mills would not be harmed. In this way, the Company exercised its rights as dominus fluminis (Hall, 1939 p.16).

Under the Dutch rule, the riparian landowners did not have special rights to the river streams that either ran across or contiguous to their property. However, owing to their physical closeness to the river, riparian owners had a greater advantage in terms of access to river water even when the Company had the power of veto over who accessed what water and in what quantities. Where landowners possessed land adjoining the courses of streams, the Company retained absolute controls over any use whatsoever of any river. The cases of Ackerman $v$ Company in 1763 and Stellenbosch $v$ Lower Owners in 1805 illustrate the fact that riparian owners did receive privileges from the Company because of their close proximity to the river, but not as a right to water (Boxes 1 and 2). As per Hall: 'It is perfectly clear that the free burghers, alongside or through whose land the water of the stream ran, had no water rights. The company gave them permission to use the water for a short period each day when it could spare it, and then it was a special favour and not a right upon which that permission was based. This certainly would seem to prove that the Company remained dominus fluminis (Hall, 1939 pp. 13-14)'.

In 1761, the Council of Policy passed a resolution that authorised the use of water for irrigating the gardens for 4 hours a day. In 1774, the Company's gardens situated downstream were allowed to have water, confirming the domimus fluminis status of the state. This principle was reinforced in the 1774 Resolution, which clearly stipulated that:

'.. the owners and occupiers of gardens are to get defined turns of water leading in such a way that the Company's undertakings are not inconvenienced and, over and above that the Burgerraden (farmers or gardeners) are given power to shut down the sluices supplying water further down - at times over and above their accorded water-leading time - should the need arise for the general good of all those involved (Hall, 1939, p. 16)'.

In 1787, the Council appointed a committee to look into the grievances of all owners of gardens in the Table Bay Valley. The committee recommended an extension of hours of water, leading to 8 hours and a system of distribution by turns. However, the Council followed the principle that the government was dominus fluminis in regard to flowing water and that it had the absolute right to grant that water to whomsoever it chose (Hall and Burger, 1974 p.2). Anyone who violated the Company's rule was punished. For example, in 1787, J.H. Redelinghuys was punished with a prohibition on water diversion as he violated an agreement on water turns (Uys, 1996 p. 193). This meant that whenever the Company gave individuals the right to water, it impressed upon them that those rights were granted as a privilege (entitlement only) which could be withdrawn at any time if it appeared to the Council that the conditions were not observed and where the water needs of the Company came under threat or were perceived to be threatened (Hall and Burger, 1974 p.3; Hall, 1947 p.2).

The term dominus fluminis was coined by the South African jurists and was not derived from Roman or RomanDutch law (Uys, 1996, p.189). The literal meaning of the term is 'the owner of the river' but it has been used to indicate that the state holds the power to control the use of water and is not necessarily the owner of the resource. To be able to fully control and legislate the use of the water, the law gave the state dominus fluminis over all rivers and water bodies of the country. This doctrine was applied in South Africa and persisted without challenge throughout the $18^{\text {th }}$ century, although the situation in South Africa was very different from that of The Netherlands. The Cape had a few perennial streams but these were not comparable to the navigable waters of The Netherlands. In the Cape, water use was mainly for consumptive purposes, and freshwater was used for domestic and agricultural purposes rather than for fishing and navigation as in The Netherlands. Despite the above facts, the writers of South African water rights laws often incorporated and cited precedence from the Dutch law or made reference to The Netherlands.

Box 1: The Case of Ackerman v. Dutch Company (1763)

J. Ackerman was a burgher who bought property and its title from a fire master, Jan Gintsenberg, who had a private arrangement with the Governor, Ryk Tulbagh, permitting him to take water from the company's wooden trough, which ran over part of his land. His land was between 2 properties which had been given turns to draw water from streams. The fire master had been well supplied with water from the Company sources and did not seek to participate in the much more restricted daily turns. After he died, his land was sold and the privileges that went with being a fire master were withdrawn from the new property owner - Ackerman. As Ackerman could no longer appropriate the Company's water for his own use, he started to bale what he required from the river. This naturally led to trouble with his lower neighbours, who compelled him to desist. Ackerman's petition to the Council stated that he could not make a living out of his garden without a supply of water for irrigating his land and requested the Council to consider allowing him to lift water from the river to his property for irrigation. The Council, after duly considering the report on Ackerman's circumstances, gave its approval for water use as a privilege, not as a legal right (Based on Hall, 1939 pp. 14-15).

Box 2: Stellenbosch Town v. Lower Owners (1805)

The Council of Policy handled the case between the town of Stellenbosch and the Lower Owners when the latter complained about the town's water use activities as limiting and in fact denying them any access to water. The Eerste River, which runs down from the town, had a very rich river base supporting market gardening ventures below the town. Many farmers owning land riparian to this river course did not have an adequate supply of water for their gardening ventures. This was the subject of several contested actions in the water court and a commission of inquiry was set up. In reacting to this case the Company's Council of Policy acted upon the principle that the Government was dominus fluminis in regard to flowing water and that it had the absolute right to grant that water to whomsoever it chose. In several of these court actions the Stellenbosch Town municipality won against the garden owners (Hall, 1939 pp. 19-20). 
The state was dominus fluminis with respect to all running water. It was also accepted that only those streams which flowed perennially were public on the authority of Voet (Hall, 1939 p.10). The doctrine of perennial streams being public and intermittent streams being private was later adopted by the courts of South Africa; the doctrine remained effective until the Cape Irrigation Act of 1906 when the intermittent streams were also added to the category of public streams (Hall, 1939 p. 10). The doctrine of state ownership of rivers and all that pertained to them (dominus fluminis) became universally recognised and persisted throughout the $18^{\text {th }}$ century in South Africa (Hall, 1939 p.10). From the foregoing discussion, the rights of ownership in land which was in contact with a running stream did not ipso jure carry with them rights to make use of the water of that stream. However, the right to make use of the water could be obtained from the state, which granted it as a privilege as opposed to legal right. Thompson (2006, p.36) sums it up nicely: 'It seems that all water was common to all during this period, belonging to no-one in ownership while the government had the right to control the use of water. Entitlements to water were determined administratively. The control was, however, tightened or relaxed according to the demand therefore, influenced by the extent of competition.'

\section{Water rights under British rule}

The British period can be subdivided into 2 sub-periods for better understanding of the periodisation of events. The $1^{\text {st }}$ period dated from 1806 to around 1910 and the $2^{\text {nd }}$ period began from 1911 onwards, when South Africa had become a Union and part of the British Commonwealth. The $1^{\text {st }}$ period can be referred to as the British colonial period and the $2^{\text {nd }}$ the British Commonwealth period.

The British consolidated their occupation of the Cape in 1806. With the British take-over of the Cape, the Roman-Dutch law was set to be toppled by the English law over the next 150 years. The British introduced administrative and organisational reforms and introduced English law. The government thus gradually lost power of granting entitlements to water from rivers and only the owners adjoining the river obtained these entitlements (Thompson, 2006 p.36). The landdroste and heemraden were replaced by magistrates in 1827 (Thompson, 2006 p.36). Later some of the functions of landdroste and heemraden were vested in magistrates by Ordinance 5 of 1848 (Thompson, 2006 p.36). In 1828 the Supreme Court was established and it was considered to be the sole authority to decide on water cases (Myburgh v Cloete) (Thompson, 2006 p.36). This was the British invention of a new legal system based on fusion of both Roman-Dutch and English laws. The British rulers in the Cape were very eager to anglicise (transform everything to reflect British control) and effected many legislative changes. The British reinforced their mission to establish David Livingstone's view of 'Christianity, commerce and civilisation' in Africa and engineered the change in all areas including water rights regulation (Nkomazana, 1998). A lot of the TrekBoers were forced further into the interior, or disenfranchised and made into British subjects.

During the Dutch rule, water was a very scarce resource relative to land; Dutch colonists hence made laws to regulate water use in the interests of the Company. By the time the British came into power, land had become relatively scarcer than water as a result of increasing immigration from Europe and the increasing populations of Trek-Boers and native Africans. All developments in water rights during the British regime thus reflected the predominance of land or agriculture (land-intensive industry) in the economy. Consequently, irrigation development played a major role in the moulding of early water policy, infrastructure, economic and social development in South Africa. Also, the institutions created by the then governments intervened in the development of water resources in favour of the White agricultural community (Muller, 2001).

In 1813, a dramatic change was introduced in land tenure by Sir John Craddock through a proclamation which had profound impacts on water rights in the colony. Craddock's proclamation provided landowners with security of tenure and devolved land ownership from state to individuals. Every lessee who met the terms and conditions was given ownership of the land. The 1813 proclamation thus introduced a change in the general attitude of public opinion towards the ownership of land. Thus the old rule of Dutch colonists of state as dominus fluminus began to struggle for survival under the more liberal British system.

As early as 1820 , the British law makers in the colony instituted preferential appointment of lawyers and officials trained in the British Isles to the Supreme Court bench in order to give a new direction to law in the country. The new judges challenged the idea of the state having the power of controlling watercourses as incomprehensible, and gradually put it to disuse. Individual rights to water were granted and courts dealt with water disputes in exactly the same manner as they handled disputes regarding land rights.

The proclamation, along with administrative and legal reforms introduced in the first 2 decades of the $19^{\text {th }}$ century, finally killed the power of the state to control water entitlements, eventually resulting into the introduction of the riparian principle in the Courts and the land. The year 1856 was a critical year since it marked the development of a new water management system using the land-based riparian principle.

A court case (Retief $v$ Louw) in 1856 (but reported for the $1^{\text {st }}$ time in 1874) marked a clear movement away from the state control of watercourses. Here the downstream owner sued the upstream owner, who had diverted the whole of the stream's summer flow and thus deprived the downstream owner of water for drinking purposes and irrigation (Hall, 1939 p. 32). The Court was called to decide the rights of riparian owners and the case was heard by Judge Bell who handled it differently from what had been expected in the past. The Court ignored the dominus fluminis principle and held that for perennial streams running over several adjoining land parcels, landowners 'have each a common right in the use of water which use, at every stage of its exercise by any one of the proprietors, is limited by a consideration of rights of other proprietors' (Hall, 1939 p. 35). The concluding passage of the Judgment by Judge Bell set out below formed the basis of the Common Law of South Africa in later years:

'I have come to the conclusion that the proprietors of lands throughout the course of a perennial running stream of water have each a common right in the use of that water, which use, at every stage of its exercise by any one of the proprietors, is limited by a consideration of the rights of the other proprietors and it seems to me that the uses to which the proprietor of land lying on the upper part of a stream may make of the water of the stream are, from the very nature of things, to be classed in the following order: $1^{\text {st }}$, the support of animal life; $2^{\text {nd }}$, the increase of vegetable life; and $3^{\text {rd }}$, the promotion of mechanical appliances; and the enjoyment of any one of these uses would seem, also from the very nature of things, to depend consecutively upon how far it deprived the owners of the lower 
land of their enjoyment of water for the same purposes. If the upper proprietor requires all the water for the support of life, for human beings and cattle upon his land, the lower proprietors must submit; if the water be more than sufficient for such animal demands, sufficient must be allowed to pass for the supply of animal demands of all proprietors lower down the stream before the upper proprietor can be allowed to use the water for the support of vegetable life, or to improve his lands by irrigation. Again the demands for the supply of animal life being answered, the proprietor of the upper ground is entitled to use water for the purpose of vegetable life...by irrigation or otherwise; so are the proprietors of the lower grounds in succession entitled to use water for agricultural purposes. Agricultural uses being supplied throughout the course of the stream, the natural use of water being thus exhausted, the proprietors are then entitled to apply water to mechanical purposes. But I apprehend that no proprietor on any part of the stream is entitled to use the water for all these three purposes, even consecutively in the order in which I have mentioned them, or any one of them, recklessly and without any regard to the wants of those below and above him (Hall, 1939 p. 35).'

This formulation was in essence the Anglo-American doctrine of riparian rights (Kidd, 2009; Milton, 1995 p.4). Judge Bell distinguished between the water rising on an owner's land and water running over his land. The water running on the land was considered public while the water rising on the owner's land was private (Thompson, 2006 p. 38). The principle of riparian ownership was imported into the South African law. The Court (Judge Bell) cited from American textbook, Treatise on the Law of Watercourses, by Joseph K Angell (1840). Some 10 paragraphs (para. 84, 93, 94, 95, 117, 120, 121, 122, 124, 128 ) of the book provided Judge Bell with all the material that he needed for making up his mind on the case (Hall, 1939 p.36). From this text South Africa's water laws also adopted the system of the proportionate sharing of the use of perennial streams by riparian owners which was evolved in the United States of America (Hall and Burger, 1974 p.4; Thompson, 2006 p.43). Further, water use was divided into 3 categories: for the support of animal and human life, increase of vegetable life, and for the promotion of mechanical appliances. Water could not be used for a specific category if all the owners along the river did not have enough water for higher category (preferential order of use). This preferential order of use further limited the riparian owners to not use water recklessly (Thompson, 2006 p. 43).

The doctrine of dominus fluminis received the other deathblow in 1869 when Privy Council suggested that when water had flowed beyond the boundaries of the land on which it rose in a known and defined channel, the lower owners became entitled to use it (Silberbauer v Van Breda) (Hall and Fagan, 1933 p. 3). The Privy Council heard appeal from judgment in Silberbauer $v$ Van Breda. The judgment was reversed and it was concluded that the Roman-Dutch principle that the owner has the absolute right to water rising on his land as per Voet was not acceptable in the colony (Hall, 1939 p.43). Furthermore, in 1875, in the case of Vermaak $v$ Palmer, Judge Smith held that the upper owner was not entitled to the unlimited enjoyment of the water rising on the land (Hall, 1947 p.26).

From 1827 to 1855 the judges appointed to the Supreme Court Bench were men such as Musgrave, Wylde, Menzies, Bell, Hodges, Burton, and Kekewich, who were all trained in the English or Scottish Law and had little acquaintance with Roman-Dutch Law. They all therefore tended to base their decisions on English authority (Hall, 1939 p.38). When Cloete and Watermeyer were appointed to the Supreme Court Bench in 1855 , they tried to reverse the process over the next 12 years by basing their decisions upon Roman-Dutch law (Hall, 1939 p. 38). But this changed again when Sir Henry de Villiers was appointed as the Chief Justice of the Cape Colony in 1873.

Chief Justice (CJ) de Villiers treated irrigation water use as res nova and laid down the principle of common use by all riparian owners. This was followed by a series of decisions by the Supreme Court which were based on English and Scottish laws that allowed riparian owners to be entitled to common use of water of a stream to which their properties were contiguous (Hough $v$ Van der Merwe, 1874; Van Heerden $v$ Wiese 1880) (Hall and Fagan, 1933 p. 3).

In his judgment of Hough $v$ Van der Merwe, Chief Justice De Villiers dismissed Voet's principles and concluded a judgment in 1874 similar to that given by Judge Bell, although the Chief Justice did not give any reference to Bell in his judgment, as follows, that according to:

'Our law the owner of the land, by or through which a public stream flows, is entitled to divert a portion of the water for the purposes of irrigation, provided - firstly, that he does not deprive the lower proprietors of sufficient water for their cattle and for domestic purposes; secondly, that he uses no more than a just and reasonable proportion of the water consistently with similar rights of irrigation in the lower proprietors ; and thirdly, that he returns it to the public stream with no other loss than that which irrigation has caused (Hall, 1939 p. 44).

The principles set out in Hough $v$ Van der Merwe were refined by the Chief Justice shortly thereafter in Van Heerden $v$ Wiese (1880), in which the court distinguished between public and private streams (Kidd, 2009). In fact, these judgments later formed the basis of water law when the task of codification was first undertaken in 1906. The most important feature of the decisions was that a sharp distinction was drawn between public and private streams bearing in mind the drier climate of South Africa (Hall and Fagan, 1933 p.4).

In 1874, the courts laid down the criteria for public and private water use and agreed that running water was res omnium communes in principle. The court defined the perennial streams as public streams which were to be used by riparian owners, while the owner of land on which a private stream rose was accorded full ownership of the water (Hall, $1947 \mathrm{p}$. 4). This however did not mean, as per Thompson (2006 p. 39), that weak water sources were excluded from being classified as res omnium communes. The flowing and running waters were public but weak and negligible streams which had no competitive uses were considered private (Thompson, 2006 p. 39). Furthermore, the use of water from a public stream was divided into ordinary and extra-ordinary uses and clear rules were laid down to guide these. Ordinary use consisted of water for the support of animal life and household use in the case of riparian owners; the extraordinary use included other uses of water for any other purposes. An upstream owner was permitted ordinary use; but was not allowed extraordinary use if downstream owners were deprived of ordinary use. Both upstream and downstream owners were allowed a reasonable share of irrigation water. The practical application of preferential ordering or reasonable use of irrigation water came before the Court in 1897 (Van Schalkwyk v Hauman); here the upstream owner had to sacrifice a part of his water for the downstream owner (Thompson, 2006 p.44).

In 1881, the question of riparian ownership was dealt with by Chief Justice De Villiers who suggested a system of apportioning water between heavy competitive uses. The court 
accepted the principle of reasonable common use by way of a system of preferential water rights (Uys, 1996 pp. 211-238). The Chief Justice further laid down some rules for reasonable sharing of irrigation water and suggested regulation between riparian proprietors according to season. For example, the upper proprietor cannot claim the same amount of water in the dry season as in the wet season, so as not to deprive the lower owner of his reasonable share (Hall, 1939 p.54).

There were several cases heard between $1750 \mathrm{AD}$ and the $1^{\text {st }}$ first half of the $19^{\text {th }}$ century where burghers raised complaints about the inadequacy of water. Most of these cases were between upper and lower stream users. These cases were handled by the court bearing in mind the riparian principle. These principles, with some change, were also applied in other neighbouring colonies of that time. For example, in the Transvaal, the legislative steps were taken to provide directions to use public water though Law 11 of 1894 of Transvaal. Later, in the Cape, Act 40 of 1899 of the Cape Colony created water courts with jurisdiction to decide all disputes and claims related to water use. The Act helped to codify the law in 1906. Thus the riparian principle, which took root in the $15^{\text {th }}$ and $16^{\text {th }}$ centuries in England (Getzler, 2004 p. 117) and was a sort of common law principle of entitlement, became entrenched in the South African water law.

Towards the end of the $19^{\text {th }}$ century the conflicts between different competitive uses of water increased due to rapid development of irrigation practices in the Cape. Although at this point in time the distinction between public and private water was very clear as laid down by various courts, the rules for the use of water were not clear which resulted in a lack of effective government control over the common use of water (Thompson, 2006 p. 50). In 1887, a well-known irrigation specialist from America, Mr Hamilton Hall, known as Ham Hall, was invited to recommend a revision of the water allocation mechanism developed by the courts (Thompson, 2006 p. 51; Hamilton Hall, 1898)). This revision, however, did not happen due to paucity of support in the parliament, and thus the riparian principle remained entrenched.

Finally, in 1906, the riparian principle was incorporated in the Act 32 of 1906 of the Cape Colony, based on previous laws and decisions of the Court during the $18^{\text {th }}$ and $19^{\text {th }}$ centuries (Thompson, 2006 p.52). The major achievement of this codification was that it codified the distinction between public and private streams (Thompson, 2006 p. 52). The 1906 Act classified both perennial and intermittent rivers as public. As a result, flood water could not be used for irrigation without storage; most Karoo rivers flowed down to the sea unchecked (Hall, 1939 p.72). In 1909 the Cape Parliament tried to remedy this by giving riparian owners the right to impound and store a reasonable share of water that might be in excess of normal flow (Hall, 1939 p. 72). This was followed by the Irrigation Act (Transvaal) of 1908. When the Union of South Africa was formed in 1910, the Irrigation and Conservation of Waters Act of 1912 (the 1912 Act) was promulgated to codify all the laws of the Union.

The 1912 Act was a compromise between the northern (Transvaal and Orange Free State) and southern (Cape and Natal) provinces. It was based on the Irrigation Act (Cape) of 1906 but was modified to tackle the situations (dry and low rainfall conditions) in the northern provinces (Thompson et al., 2001 p. 12). In this Act, the characteristics of a public stream were changed by substituting 'general common use' with 'common use for irrigation' and also the concepts of normal and surplus flows of water were innovated and used ingeniously (Hall and Burger, $1974 \mathrm{p}$. 6). As per this Act, a public stream was defined as a natural stream of water which, when it flowed, flowed in a known and defined channel, and of which the water was capable of being used for common irrigation (Uys, 1996 p. 252). The normal flow was broadly defined as the perennial part of the flow of the river, while the surplus water referred to irregular high flows after heavy rains (Thompson et al., 2001 p. 12). Riparian users were given rights to use public water which was redefined as the normal and surplus flows of a river. The normal flow between riparian owners was subject to apportionment, but they were allowed to use surplus water to the greatest extent that they could beneficially use it; private water was provided if it rose on the owner's land (Thompson et al., 2001 p. 12). In sum, the 1912 Act divided water into public (res communis) and private (res privatae). The public water was further divided into surplus and normal flows. The normal flow was subject to common rights of use and surplus water to serviceable exclusive rights of use, while private streams were subject to unlimited exclusive rights of use (Uys, 1996 p. 259). Thus the concept of perenniality was finally abandoned in the Act of 1912 and was categorically replaced by 'surplus flow' and 'normal flow'.

It is noteworthy that although the Act of 1912 recognised riparian rights as dominant, there was provision for grants to non-riparian owners to use water not utilised by riparian owners (Nunes, 1975; De Wet, 1979). About 40 Acts were promulgated to circumvent water court orders in order to carry out water projects. Later, these Acts were repealed by the National Water Act of 1998 (Thompson et al. 2001; Kidd, 2009).

It is to be noted that through the British title deed system, the colonial government granted land titles to members of the White minority over $91 \%$ of the territory; thus, by adopting riparian rights throughout South Africa, instead of the RomanDutch permit system, the 1912 Act vested most of the rights to water resources in Whites only (Van Koppen, 2005). Thus it discriminated against the Black majority.

The Union's policy at that time was to encourage largescale irrigation projects and instituted restrictions on riparian rights. As a result, the court had to adjudicate between the government and riparian owners whenever major water works were constructed. It finally resulted in a chaotic situation as the state did not invest actively in water infrastructure and apportionment of water became the exclusive function of the judiciary (Thompson et al., 2001 p. 12; Thompson, 2006 pp. 57-58).

The disparity between the principles of Dutch water rights and those of the British can be understood from the viewpoint of input scarcity. For example, when the Dutch arrived in the Cape, land was abundant but water was scarce. By the time the British occupied the Cape, land had also become a scarce resource due to rising immigration from Europe and increasing populations of the Trek-Boers and native Africans. As a result, water rights became largely tied to land tenure and riparian water rights became the mainstay and legacy of British water rights policy in South Africa.

The key to understanding water rights under the British regime lies in the way that they viewed different water resources in the colony and then modified the riparian principle to suit different situations. For example, after gold was discovered in the Johannesburg area in 1866, they established the Rand Water Board in 1903 in the greater Witwatersrand area and gave water rights to mines on a priority basis with the sanction of law (Lewis, 1934); this promoted movement of settlers to the Johannesburg town (Turton et al., 2006). The two 
important aspects of the British water rights that need special mention are: categorisation of water rights by forms of water, and the riparian principle superseding state control.

\section{Categorisation of water rights}

The British recognised that South Africa had very limited water resources in rivers, dams and under the ground. Water regulation was therefore designed to accommodate differences that arose due to forms of water (surface versus ground). For the first time in South African history, the distinction was made between forms of water by the judicature in 1856 and clear distinction between surface water and groundwater was drawn in 1876 (Thompson, 2006 pp. 37-40). The first important category of water was surface water which included rivers, streams and springs. The rivers, not streams, were considered public. In 1874, courts agreed that all running water was res omnium commune (Thompson, 2006 p. 38).

The water-related legislation enacted in these early years was hence aimed at protecting the water rights of farmers along rivers. Thus irrigation development was one of the major objectives of the British water rights regime. The development of irrigation in South Africa occurred in 3 phases. In Phase 1, up until 1875 , weir diversions or pump schemes were based solely on private individual initiative and the economy at this stage was characterised by subsistence agriculture. Phase 2 began with the introduction of cooperative flood diversion schemes in the Cape with loans provided by the government. It was an agriculture-with-mining development phase in the country. Phase 3 included the storing of water through dams during the 1920 s, and government promoted the settlement of people on the land. (SANCID, 2009) ). This was an agricultural-miningindustrial development stage. The river water was primarily used for irrigation which made river water the most important resource in the evolution of water use in South Africa (as irrigation was generally done by direct diversion of water from rivers) (DWAF, 1986). The state concentrated on the construction of dams on rivers to provide irrigation water to agriculture, especially after the 1920s. This did delay the development of comprehensive legislation to control and regulate the use of water and brought agricultural and industrial water users into conflict as the legislation could not suit both. The industrial users' lobby became very strong. The Water Act (54 of 1956) was designed to meet the needs of all urban, industrial and agricultural users, and legal mechanisms were created for industrial and urban users to obtain water rights (Thompson, 2006 pp. 61-62).

The ownership of water rights emanating from a river source was closely linked with land rights. The ownership of land contiguous to a river source advantaged the landowner and disadvantaged those who were not owners of such land. The mere fact that the owner of riparian land had sold his right to use water on that land did not deprive the land of its riparian characteristics (Hall and Burger, 1974 p. 23). For example, in the case of De Wet v. Estate F. J. Rossouw, the water of a public stream was divided between the 2 riparian owners who had a dispute between them. A riparian owner who had received a share in water acquired another piece of land $\left(2^{\text {nd }}\right.$ piece $)$ which was not entitled to water. However, he proposed to use his water entitled from the $1^{\text {st }}$ piece of land on the $2^{\text {nd }}$ piece of land, to which the other riparian owner objected. The court held the case in favour of the latter stating that subsequent apportionment of water to the $2^{\text {nd }}$ piece of land was not rightful (Box 3).

\section{Box 3: De Wet v. Estate F. J. Rossouw (1926)}

In the case between De Wet (applicant) and Estate F. J. Rossouw (respondent), the applicant received (under an agreement between owners which was confirmed by court judgment) an allocation of the use of a share of the water of the Hex River, as owner of a portion of the farm Oudewagendrift and of the adjoining farm Tweefontein. In this case he proposed to take some of this water to another portion of Oudewagendrift acquired by him. The share of water (from the Nonna River) allocated to this portion (to be called the $2^{\text {nd }}$ portion hereafter) was disposed of to others and thus the applicant purchased the ground without any rights to water. Both pieces of land were situated in the same watershed and were riparian to the Hex River. The respondent in this case objected that the applicant had no right to use water. The respondent based his objection upon 2 contentions. The first is that the applicant's $2^{\text {nd }}$ portion can receive no water from the Hex River, as it is no longer riparian to that river in the sense that the water rights were already sold to another party. The $2^{\text {nd }}$ contention was that the use of the applicant's water was allocated to a certain definite area and that its use is inseparable from such area, therefore the applicant had no right to use this water on any other ground than that to which it has been allocated. The court decided in favour of the respondent (Hall, 1963 pp. 156-167).

The $2^{\text {nd }}$ important category of water use was groundwater which was seen as a resource supplementing surface water use. Groundwater was defined as all water naturally existing under the ground, whether in a defined channel or not (Vos, 1978 p. 20). Groundwater rights have also gone through several changes. For example, an indirect reference to groundwater by the judicature was made by Judge Bell in the case of Retief $v$ Louw (Uys, 1996 p. 397). In the case of Mouton $v$ Van der Merwe in 1876 the court raised doubt as to the validity of Voet's view that water which burst out on one's land was one's property just like the groundwater beneath one's land (Uys, 1996 p. 397). As early as 1914, concerns arising from groundwater were heard in different water courts of the country. One such case was that of Smith v. Smith in 1914 where it was considered a 'fundamental principle that the owner of land owns a centro ad coelum and accordingly groundwater is the absolute property of the land owner with the exception that if the underground water is public' (Vos, 1978 p. 24). Where groundwater was flowing in a common public stream, which was a perennial stream capable of being put to the common use of the riparian proprietors, such groundwater was considered as public (Vos, 1978 p. 24).

The $3^{\text {rd }}$ category of water use was dam water. Having acknowledged the limitation of river water resources and the complications associated with using groundwater resources, the British colonists turned to dams as a very important water resource in South Africa. Water courts allowed water rights for storage of water upon the land of an adjoining owner.

\section{Riparian principle superseding the dominus fluminis}

By the time the English took control of the Cape, the land and water were both under the control of the Company (VOC) and water rights were not tied with the land. This meant that the ownership of land did not automatically include the right to divert and use the water of a permanent stream flowing through the land (Hall, 1939 p.27). At this juncture in history, 2 land tenure systems existed: the loan-farm or leningplaat and quitrent. The loan-farm system was introduced by the Company in 1714 and under this system the land was leased to the holder who paid annual rent plus stamp duty (Duly, 1968; Hodson, 1997); the lease was renewed from year to year. The ownership of land and water however rested with the Company. 
The quit-rent system was started in 1732 and land under this system was leased for 15 years and the name of the holder was registered with the government (Duly, 1968). However, as usual under the Dutch regime, the ownership was with the Company. This was a slightly better system as the landholder could plan and do things with the land under the 15-year lease period. With the coming of the British in 1795, the tenure system was modified. British tied water rights with the land as 1 package and Sir John Craddock's proclamation of 1813 gave landowners security of tenure. Craddock adopted the quit-rent model and land holders were asked to convert to quit-rent tenure. Although the process took some time, it finally succeeded. This speeded the process of adoption of a riparian system of water rights in the Cape.

The ownership of riparian land gave automatic access to water that flowed from the adjoining land. A riparian owner was given the right to use all the water of a public stream provided that it was used in a 'reasonable' manner. This, however, favoured the upper as opposed to lower owner along the public stream. Thus the British system put a lot of trust in the hands of individuals and incentivised them to make a transition to the riparian system of water rights.

The appointment of Sir Henry de Villiers as the Chief Justice of the Cape Colony brought the riparian principle into full practice in 1873 and it remained effective until 1956. After 1956 there was a clear move away from riparianism; the Minister had the power to declare government water control areas and could then allocate water to non-riparian land.

The British rule thus established and practiced the riparian principles and literally eliminated the dominus fluminis status of the state in the land. It is interesting to note that when Americans fought against the riparian principle in Colorado and other western States of the USA, South Africa continued to cling to the riparian principle despite it not being suited to a dry country. In America, the riparian principle was finally rejected in 1928 by the California Court.

\section{Revival of the dominus fluminis under Apartheid}

The National Party (NP) came to power in 1948 and introduced the system of apartheid. The NP government introduced large water projects to encourage economic development in rural areas where a large part of the NP's support base was located (Turton et al., 2004). Under the apartheid regime, the $1^{\text {st }}$ milestone in the water rights history of South Africa was the Water Act of 1956 (Act 54 of 1956). The Water Act of 1956 has been hailed as representing a very important piece of legislation in the history of water regulation in South Africa. This Act managed to harmonise water regulation in the interests of the economic heavyweights, agriculture, mining and industry. According to the Department of Water and Affairs and Forestry (DWAF, 1986), the Act came closest to:

'.. ensuring equitable distribution of water for industrial and other competing users, as well as to make possible strict control over abstraction, use, supply, distribution and pollution of water, artificial atmospheric precipitation and the treatment and discharge of effluent (DWAF, 1986, p. 1.9).'

The Republic at this stage was sufficiently industrialised and the urban population had grown. The political context had also changed and the country was ruled by the Afrikaner nationalists. The increasing demand for water from urban and industrial sectors during the $1^{\text {st }}$ half of the $20^{\text {th }}$ century placed an additional burden on the limited water resources. The increased demand could not be accommodated by the traditional riparian principle. Thus the 1912 Act could not meet the expectations of a growing industrial economy. Increased competition for water use necessitated a change in the law. In 1950, a Commission of Inquiry into Water Matters under the chairmanship of C. G. Hall, known as the Hall Commission, was appointed and on their recommendation, the Water Act of 1956 was promulgated. In brief, the new Act moved away from the riparian rights principle, which worked well as long as water was used primarily for agricultural purposes (De Wet 1959 p. 35). The Irrigation Department was then renamed asthe Department of Water Affairs to reflect its broadened scope.

This required provisions for the domestic as well as industrial uses of water. The Act vested in the Minister of Water Affairs a large measure of the control of public water through the principle of government control areas.

The key principles of the 1956 Act were:

- Riparian ownership is a workable system; however, final control of water resources is with the state

- Strict state control on industrial and groundwater uses was advocated.

The Act permitted the government to declare 'control areas' where the control of water was deemed by the Minister to be desirable in the 'public' or 'national' interest. These control areas included subterranean government control areas (s28), government water control areas (s59) which in turn could be declared irrigation districts (s71 and s73), government drainage control areas (s59 (5)) catchment control areas (s59 (2)), dam basin control areas (s59 (4) (a)) and water sport control areas (Kidd, 2009). By the Act of 1956 the state was thus re-invested with dominus fluminis status for all practical purposes, bearing in mind the increasing demand for water and the fixed water supply. The state defended this status on the basis that increasing scarcity of water in the country required state interference for the purpose of rationing and development of water resources of the country. The use of public water for industrial purposes was subject to the permission of a water court orthe Minister (s11 (1)), but the industries which were supplied with water by the local authorities were not required to have water court permission (Kidd, 2009). Control over urban and industrial users was also exercised by the introduction of the Water Boards. They made provision for bulk water for urban and industrial use and for regional sewage schemes in the area of their jurisdiction. Measures were also introduced to control water pollution activities.

The Water Act 54 of 1956 replaced the Irrigation Act of 1912. The Act partially entrenched the riparian rights and brought back dominus fluminis status of the state through government control areas. The distinction between the public and private water from the previous Act was retained and refined further. The idea of public water and its classification into normal flow (which would be divided between the riparian owners) and surplus flow (where, in flood times, riparian owners could take as much surplus as they were able to use beneficially), which was introduced in 1912, was further improved. The right to use public water was divided into agricultural, urban, and industrial purposes. A riparian owner was permitted to use water for the purposes of agricultural and urban use only. This riparian owner could use a share of normal flow and all the surplus water for beneficial agricultural and urban purposes. The groundwater could also be classified as public and private. Groundwater not defined either public or private was subjected to commonlaw principles. 
The colonial water rights policy excluded the Africans who could not compete in the land markets freely and also did not have the resources to do so where such access was possible. Around 1900, various legislations were aimed at dispossessing Black Africans. For example, legislation such as the Native Land Act (27 of 1913) (dividing the land between Black and White people), the Development Trust and Land Act (18 of 1936) (preventing Africans from owning land in their own right), and the Group Areas Act (41 of 1950) clearly controlled the majority Black people's access to land and hence to water (Stein, 2005). At the same time, the Land Bank of South Africa was mobilised to help White farmers as part of a policy to reduce White unemployment.

In addition to the original provinces comprising the Union of South Africa (Transvaal, Orange Free State, Natal, and Cape), there were 4 independent and autonomous states and 6 self-governing territories - formation of these states was a policy of apartheid to create separate jurisdiction for the original inhabitants. These territories and states had legislative power to repeal, amend or replace the 1956 Act. However, none of them, except Bophuthatswana, made any changes to the Act. Bophuthatswana adopted the dominus fluminis principle into law in 1988. In a nutshell, the right to the use of water continued to be based on the principle of dominus fluminus as the majority of land was state owned in these national states and self-governing territories; the land ownership in these states was governed by African customary law (Thompson et al, 2001).

\section{Water rights under democratic rule (1990s onwards)}

The most important challenge for post-apartheid democratic South Africa with its neo-liberal inclination was to find the balance between the traditional view that water is a public good and the modern view that water also has a commercial value. The current legislative framework made a marked shift from previous water laws; it sought to address the social inequities and environmental concerns on the one hand and efficiency-related issues on the other. The Constitution of South Africa, which was finally adopted in 1996, contains a Bill of Rights (Chapter 2) that ensures rights of individuals to environment and water. The concerns relating to social inequities and environment are of paramount importance in the South African Constitution. Section 24 provides that 'Everyone has the right (a) to an environment that is not harmful to their health or wellbeing; and (b) to have the environment protected, for the benefit of present and future generations, through reasonable legislative and other measures that (i) prevent pollution and ecological degradation; (ii) promote conservation; (iii) secure ecologically sustainable development and use of natural resources while promoting justifiable economic and social development.' Section 27 provides for the right to water as follows: '(1) Everyone has the right to have access to (a) healthcare services... (b) sufficient food and water; ...(2) The state must take reasonable legislative and other measures, within its available resources, to achieve the progressive realisation of each of these rights (RSA, 1996 pp. 11-13).' These 2 fundamental rights form the backbone of South African water law. Also, water is classified as a resource of exclusive national competence as it does not appear in Schedule 4 and 5 of the Constitution, thus confirming its significance to the country (RSA, 1996).
Although the Act of 1956 had been seen as a reversion towards a state as dominus fluminis, as it made provisions for increasing government control over water, the government powers were not widely used to dilute the riparian rights in essence (Kidd, 2009). The 1956 Act was heavily based on riparian rights, privileging White riparian farmers and excluding the majority of South Africans from access to water rights (WLRP, 1996). The Recommendations of the Water Law Review Panel formed the basis of the White Paper on a National Water Policy for South Africa (DWAF, 1997). The White Paper indicated that in 1997 about 12-14 m. South Africans (out of $40 \mathrm{~m}$.) were without access to safe water and over $20 \mathrm{~m}$. without access to adequate sanitation (Kidd, 2009). The new development vision of the country - the Reconstruction and Development Programme - formed the basis for overhauling the legal system and building new laws, including water laws, for its people.

The new water law was built on some 28 basic principles as discussed in the White Paper (DWAF, 1997). The first 4 key principles laid the legal foundation of the law and these stated that: the water law is to be subjected to and also be consistent with the Constitution (Principle 1); all water, irrespective of its occurrence in the water cycle, is a common resource and its use is subject to national control (Principle 2); there is no ownership of water but only a right (environment and basic human needs) or an authorisation for its use; and any authorisation is not granted in perpetuity (Principle 3).; the riparian principle is abolished (Principle 4). The $2^{\text {nd }}$ set of principles related to recognition of water cycle as resource (Principles 5 and 6). The $3^{\text {rd }}$ set of principles which guided the water resource management priorities clearly laid the ground rules for water managers of the country, suggesting that: the objective of managing water (quantity, quality, and reliability) is to achieve optimum, long term, environmentally sustainable social and economic benefit for the society from their use (Principle 7); the access to water for all and water required for meeting ecological functions are reserved (Principles 8 and 9). The use of water for meeting basic human needs and the needs of the environment are reserved and prioritised. The international obligations through treaties and rights of neighbouring countries are to be recognised (Principle 11). The $4^{\text {th }}$ set of principles (Principles 12-21) related to water management approaches. These principles allude that the National Government is the custodian of the water resources of the nation (Principle 12); the National Government would meet this mandate by ensuring that the development, apportionment and management of water resources is carried out using the criteria of public interest, sustainability, equity, and efficiency while recognising the basic domestic needs, plus the requirements for meeting environmental and international obligations (Principle 13), and so on. Principles 22 to 24 are to guide the development and functioning of water institutions, while Principles 25 to 28 relate to provisioning of water services to people.

As mentioned earlier, the development of water rights in South Africa is largely hinged upon Roman-Dutch law in which rivers were seen as resources which belonged to the nation as a whole and were available for common use by all citizens, but which were controlled by the state in the public interest - this is sometimes known as the 'public trust doctrine'. The concept of public trust goes back to Roman times. The Roman Emperor Justinian codified the law in 528 AD, which has been known as the Institutes of Justinian (Lee, 1956 pp. 33-45). The Institutes of Justinian stated that by the law of nature some things are accepted as common to mankind such as air, seashore, etc. These are defined as 'commons' in 
today's parlance. This public trust doctrine was later adopted by England's legal system and was a part of the Magna Carta in 1215 AD. The Magna Carta sought to limit the powers of the king and prevented him from giving exclusive rights to noblemen to hunt or fish in certain areas. The King owned the land but he was obliged to protect it for the use of the general public. The English Common Law developed though decisions made by judges and they twisted the Roman notion of common property and defined that common properties were held by the king for the benefit of subjects. The king held them 'in trust' for the benefit of all citizens. The idea of trusteeship was finally incorporated into the South African law after the democratic transition in the country. These principles were closely in line with African customary law which saw water as a common good used in the interests of the community. The public trust principles are entrenched in the Fundamental Principles and Objectives for a New Water Law in South Africa (Principles 12 and 13) (WLRP, 1996).

National government is designated the public trustee of the nation's resources to 'ensure that water is protected, used, developed, conserved, managed and controlled in a sustainable and equitable manner, for the benefit of all persons and in accordance with its constitutional mandate' (NWA, 1998 s3 (1)). The Minister of Water Affairs and Forestry was given the executive responsibility to ensure that water is allocated equitably and used beneficially in the public interest, and that its environmental values are protected (NWA 1998, s3 (2)). Equitable access was considered very important due to the discriminatory policies of the past. The idea of public trust in the South African law gives the overall responsibility and authority to the national government of the country; it has never meant that government owns the water resources (Thompson, 2006, p.279)

Having met the constitutional mandates towards basic human needs, environmental requirements, and international obligations, the White Paper suggested that the framework of the market be used to effect efficient use of water (DWAF, 1997 s6.5.3). Setting the appropriate price for water is sought as an effective mechanism to achieve its efficient and productive use (DWAF, 1997 s6.5). That is, in a free enterprise economy, pricing the water was considered as the best way of rendering a balance between supply and demand and preventing wastage of water. Cabinet decided in February 1996 that the price of water for major users should progressively be raised to meet the full financial costs of making the water available and to reflect its value to society (DWAF, 1997 s6.5.1). In drafting new water tarrifs, 2 important principles were thus utilised:

- The riparian principle of water allocation was replaced by the principle of water permits (administrative water rights, licenses, concessions, authorisations)

- The principle of separation of public and private water rights.

Keeping these social values in mind, the South African Parliament passed 2 laws:

- The National Water Act (NWA) of 1998

- The Water Services Act (WSA) of 1997.

\section{National Water Act 1998}

The National Water Act of 1998 repealed over 100 Water Acts and related amendments and extinguished all previous public and private rights to water (NWA 1998, Schedule 7). The government was given the responsibility to sustainably manage the nation's water resources for the benefit of all persons in accordance with its constitutional mandate (NWA, $1998 \mathrm{~s} 3$ ). The purpose of the Act is to ensure that the water resources of the nation are protected, used, developed, conserved, managed and controlled in ways which take into account the following (NWA, $1998 \mathrm{~s} 2$ ):

- Meeting the basic needs of present and future generations

- Promoting equitable access to water

- Redressing the results of past racial and gender discrimination

- Promoting the efficient, sustainable and beneficial use of water in the public interest

- Facilitating social and economic development

- Providing for growing demand for water use

- Protecting aquatic and associated ecosystems and their biological diversity

- Reducing and preventing pollution and degradation of water resources

- Meeting international obligations

- Promoting dam safety,

- Managing floods and droughts

The purpose of the NWA is to reform the water law in the country and to this end the Preamble of the Act:

- Recognises that water is a scarce and unevenly distributed natural resource which occurs in many different forms which are all part of a unitary inter-dependent cycle

- Recognises that while water is a natural resource that belongs to all people, the discriminatory laws and practices of the past have prevented equal access to water and use of water resources

- Acknowledges the National Government's overall responsibility for and authority over the nation's water resources and their use, including the equitable allocation of water for beneficial use, the redistribution of water, and international water matters

- Recognises that the ultimate aim of water resource management is to achieve the sustainable use of water for the benefit of all users

- Recognises that the protection of the quality of water resources is necessary to ensure sustainability of the nation's water resources in the interest of all water users

- Recognises the need for the integrated management of all aspects of water resources and, where appropriate, the delegation of management functions to a regional or catchment level so as to enable all to participate (Thompson, $2006 \mathrm{p}$. 199)

The National Government, acting through the Minister, is appointed as a public trustee of the nation's water resources and must ensure that above objectives are met. The NWA (1998) makes provision for the following:

- The establishment of a water resource planning regime though the National Water Resource Strategy (NWRS) and the development of catchment management strategies (Chapter 2)

- Protection of water resources through the classification of water resources and their quality and the determination of a Reserve (Chapter 3)

- The establishment of permissible use of water and entitlements to use water, and administration of the entitlements (Chapter 4)

- The pricing of water use and provision for financial assistance (Chapter 5) 
- Creation of catchment management agencies (CMAs), water user associations (WUAs), and advisory committees (ACs) ( Chapters 7-9)

- Establishment of bodies to implement international agreements (Chapter 10)

- Construction and control of water works and storage, and dam safety (Chapters 11-12)

- Access to and rights over land (Chapter 13)

- The establishment of a national monitoring and information system (Chapter 14)

- Appeals and dispute resolution, offences and remedies (Chapters 15 and 16)

The National Water Act recognises that water is a scarce and unevenly distributed resource, belonging to all people, and that no discriminatory law should be established to prevent access by others and that sustainability should be the aim in distribution through which all users could derive benefits. Until very recently, river water resources were regarded as public while groundwater was considered private. The new Act has called for the uniform protection of all significant water resources, emphasised resource sustainability and the principle of integrated water resource management; the Act attempts to redress the problem of past groundwater mismanagement by presenting a number of policy principles for guiding of groundwater protection strategies (Van der Merwe, 2000 pp. 16-18).

The Act defines water use in Section 21 (Chapter 4 of NWA, 1998) very broadly, covering 7 types of water uses which include ((DWAF, 2004 p.63):

- Abstracting water from a water resource (s21 (a))

- Storing water (s21 (b))

- All aspects of waste disposal which impact water resources (s21 (f) and (g) and (h))

- Removing, discharging or disposing of water found underground (s21 (i))

- Making changes to the physical structure of watercourses (s21(c) and (j))

- Some activities such as stream flow reduction activities (s36, s37 (1), s38 (1))

- Water for recreational use (s21 (k))

The Act regulates water use and makes provision for authorisations of water use in 3 ways:

- Schedule 1 authorisations

- General authorisations

- Water use licences

Schedule 1 permits the use of relatively small quantities of water, primarily for domestic purposes, which is exempted from the requirement for licensing. A general authorisation conditionally allows limited water use without a licence. Any water use that exceeds a Schedule 1 use, or that exceeds the limits imposed under general authorisations, must be authorised by a licence (DWAF, 2004 pp. 64-65). A water use licence is valid for specified time period (not exceeding 40 years) with conditions attached to it and must be reviewed by the responsible authority at least every 5 years (DWAF, 2004 p. 66).

The National Water Act also provides for a pricing strategy for all water uses defined under Section 21. Three types of water charges are provided for by the Act. These include: water resource management charge, water resource development charge, and an economic charge for the value of water to particular users (DWAF, 2004 p. 83). The first 2 charges management and development - are financial charges which are directly related to the costs of managing water resources. The $3^{\text {rd }}$ economic, charge is to usher efficiency in water use across various types of water uses.

As per the authorisation mechanisms, the law permits/enables those affected by decisions regarding licensing to voice their opinions, and gives them the right to be provided with reasons for a licensing decision. It also gives them the right to appeal against a decision that might be unfavourable towards their interests. The legal mechanism necessitates the use of economic instruments such as pricing mechanisms and financial assistance or subsidy programmes (Stein, 2002 p. 119). This instrument ensures that hedonistic users of water pay for the resource. Although pricing of water is a problematic issue in South Africa as many cannot pay for it, especially in rural areas and in the case of slum dwellers in cities, all significant private and public entities are expected to pay for their water use.

For successful management of water resources, an integrated or coordinated development and management of water (IWRM), land and related resources is recommended in order to maximise the resultant economic and social welfare in an equitable manner without compromising the sustainability of ecosystems (Thompson, 2006 p. 162). The hierarchy of water management institutions in the country is thus comprised of 3 levels:

- Minister of Water Affairs and Forestry at the national level

- Catchment management agencies

- Water user associations

After country-wide consultation, some 19 water management areas (WMAs) were established in the country. Catchment management agencies (CMAs) are statutory bodies with jurisdiction in a defined WMA. Integrated water resource management is to be done in South Africa on a catchment basis. The efficiency aspect is further strengthened by decentralisation of decision making to the catchment level, through the catchment management agencies (CMAs).

The Department of Water Affairs (DWA, formerly the Department of Water Affairs and Forestry (DWAF)) is now fully responsible for administering all aspects of the Act on the Minister's behalf. This role will diminish as regional and local water management institutions are established. The eventual role of the DWA will be to provide national policy and a regulatory framework and to maintain general oversight of the institutions' activities and performance. In the long run, the responsibility for operating and maintaining infrastructure will be transferred to the CMAs and WUAs. Each CMA is to develop a catchment management strategy for managing water. The local execution of the catchment management strategy is done by the local organisations such as WUAs and others. At a later date, the CMAs may be given the financial and administrative responsibilities for setting and collecting water user charges (Tewari and Kushwaha, 2007). Functions and responsibilities of CMAs include:

- Development of strategy in the catchment to meet the objectives of the Act

- Management of water resources and coordination of the water-related activities of water users and other water management institutions within the WMAs

- Additional functions may be delegated to the CMA by the Minister.

The licensing system is thus more flexible and more rational in allocating water across various uses than the riparian principle. However, at the same time, the pricing mechanism ensures that 
hedonistic users of water pay for their use. The licensing principle has thus replaced the riparian principle of the past.

\section{Water Services Act 1997}

The 'White Paper on Water Supply and Sanitation' was published in November 1994. This was followed by the Water Services Act (108 of 1997) (WSA). The Act delineates the provisions for regulating the activities of water service providers, focusing on the roles and functions of the various water service institutions responsible for providing water and sanitation services. The key objective is to ensure the effective partnerships between various water institutions so as to ensure the sustainable water use in the country. The WSA of 1997 declares that every person has a right of access to a basic water supply and basic sanitation and it is the part of service providers to take reasonable measures to realise these rights (WSA, 1997). The main objectives of this Act are to provide for (WSA 1997; Thompson, 2006 p. 205-206):

- The right of access to basic water supply and the right to basic sanitation necessary to secure sufficient water and an environment not harmful to human health or well-being

- The setting of national standards and norms and standards for tariffs in respect of water services (Chapter 2)

- The preparation and adoption of water services development plans by water services authorities (Chapter 3)

- A regulatory framework for water services institutions and water services intermediaries (Chapters 4 and 5)

- The establishment and disestablishment of water boards and water services committees and their duties and powers (Chapters 6 and 7)

- The monitoring of water services and intervention by the Minister and the different members of the Executive Councils responsible for local government in all the provinces (Chapter 8)

- Financial assistance to water service institutions (Chapter 9)

- The gathering of information in a national information system and the distribution of that information (Chapter 10)

- The accountability of water service providers

- The promotion of effective water resource management and conservation.

Citizens who are poor and cannot pay for water are entitled to free basic water use as per the Water Services Act; that is, about $25 \ell$ per person per day. The issue has gone to court, which ruled in favour of people's rights to free basic water, thus requiring the state to make arrangements for this (Tewari, 2008). By June 2008, some $41.7 \mathrm{~m}$. people out of a population of $49.4 \mathrm{~m}$. were served with free basic water (Tewari, 2008). This is an impressive achievement for a new democracy like South Africa. It is estimated that implementing the free basic water policy could cost about ZAR8/k $\ell$ for treatment of water and thus a free allocation of $6 \mathrm{k} \ell /$ month would cost roughly ZAR50/household each month (Muller, 2008). Durban Municipality provides $6000 \mathrm{l} /$ household to all without any charge. Similar trends are followed elsewhere in the country.

The new water laws thus recognise that water is a very scarce resource which needs to be used efficiently and equitably. Treating water as a public good gave the legislators the power to regulate who gets water in what quantities. However, the laws also recognise that efficient allocation can only be achieved though market forces and true scarcities of water can only be reflected by price. Part of this policy is that it regards water as a scarce resource and therefore hedonistic users should be made to pay. As a result of this view, stepped tariffs and penalties for excessive water use are advocated alongside life supplies for the poor. Water rights management in this period can best be seen as a mix of demand-side management, increasing block tariffs, cross-subsidies and a minimum amount of free water per month. It is therefore possible to provide the water at a certain price for various users and uses. The concept of 'water marketing' is thus advocated as means of reallocating scarce water supplies in South Africa and the Act may not impede the development of water markets in South Africa (Schwulst, 1995 pp. 38-39).

\section{Drawbacks of the new system of water rights}

Although the new system of water rights is far superior to the old one and is in line with international trends in water legislation, or the modern water rights structure, it is not free from drawbacks (Hodgson, 2006; Kidd, 2009). One major drawback of the new system is that of the state as the public trustee of the country's water resources - water allocation is done through a licensing system which increases the administrative burden of DWA. Hence some have described it as 'unnecessarily interventionist legislation' as the efficient allocation of water is finally guided by market forces (Bronstein, 2002 p. 469; Kidd, 2009). Kidd, however, considers this not to be a serious problem and suggests that the temptation to use powers provided by the National Water Act where this is not necessary should be resisted, for all reasons and at all times (Kidd, 2009).

It is to be noted that licences or permits are temporary in nature and are issued at the discretion of the Minister. The permits or licences are not transferable. That means the present owner cannot pass the rights on to his/her successor-in-title. This is especially important with respect to irrigation where an owner may lose interest in developing his/her land. This may decrease long term investment in water infrastructure, in particular in that which is in private hands.

The large bureaucracy required to administer the new law may impede the real purpose of water management if it succumbs to pressure of corruption and non-transparent dealing. This would very largely depend upon the general health of institutional integrity and political systems and the morals of society in general. If the corruption factor goes uncontrolled, it could result in complete failure to meet the ultimate objectives for which the policy and legislative change was initially sought by the democratic government.

\section{Conclusions and policy lessons}

The main factors determining the course of development of water rights over the last three and a half centuries in South Africa has been the relatively low water availability (as a factor of climatic conditions and hydrology) compared to rising water demand by various users (ranging from domestic and primary users to secondary users in agriculture, industry, construction and mining). In addition, the demand has been exacerbated due to environmental needs and other international requirements. Various phases can be identified in the evolution of water rights in the history of modern South Africa. Prior to the arrival of the settlers (both Dutch and British), water rights under African customary law were unwritten and only considered as essential when a community came under threat from another encroaching tribe. Otherwise, during this period, water rights like land were not privatised and water was a community resource. 
The immigration of settlers from Europe introduced a new beginning in terms of re-defining water rights in the country. The $1^{\text {st }}$ phase in the evolution of water rights in South Africa began with the Dutch East India Company rule which opted for the Roman Dutch law. Under this dispensation the status of the Company or state as dominus fluminis to water rights was upheld. During this period, only individuals held temporary and revocable rights to water where such rights did not undermine the Company's access to water. This phase can be said to have been the longest, spanning from 1652 up until British rule in the $1^{\text {st }}$ decade of the $19^{\text {th }}$ century (about 1810). The company treated water as a public commodity and assumed full control of the resource.

The $2^{\text {nd }}$ phase included the period of British control, from the early $19^{\text {th }}$ century up until the beginning of Afrikaner rule (1810 to 1952). The British were more liberal than their predecessors and allowed individual rights over water as with land tenure. This led to the codification of water rights and the granting of riparian rights to individuals. Water sources were defined and categorised in order to systematise the water rights regulations. Differences between private and public river streams were clarified and so were the different rights emanating from them. The British approach to water rights was exactly opposite to that of the Dutch East India Company. The British permitted private rights to water to be held by individuals, unlike the Dutch rulers who treated water as a public commodity. The key legislation of this period was the Irrigation Act of 1912. However, as time passed, the Irrigation Act, despite amendments, became inadequate to cope with the social and industrial progress of the nation.

The $3^{\text {rd }}$ phase in making water laws began with Afrikaner rule or the apartheid period. The 1912 Act that was passed under British rule was repealed and a comprehensive codification of water laws in the form of the Water Act (No. 54 of 1956) was passed. The country at this stage was sufficiently industrialised and urbanised. This required that provision for water should be made available for all sectors. The new law under apartheid rule promoted the segregation of development on different paths for the different races. The 1956 Act did represent a fundamental change in terms of policy direction by regulating the access to and availability of water for the mining and manufacturing industry. Afrikaner nationalists revived the dominus fluminis rule through the principle of government control areas where the control of water was deemed by the Minister to be desirable in the public or national interest.

The $4^{\text {th }}$ phase refers to the current democratic South Africa where the main thrust on water rights is to facilitate access to water for communities which were previously disadvantaged by the deliberate segregation policies. At the same time, the policy aims at providing water to users in such a way that development is promoted without compromising the sustainability of the resource. It implies that water rights in the current phase are more inclusive and focus on development and sustainability within the context of equitable distribution, justice and human dignity. However, water is still res omnium communes with the government through the Minister as trustee. The Minister and the central government are hence given the role of custodian of scarce water resources so as to use it in the best interests of nation and people. Both efficiency and equity are key objectives of this law.

A review of water rights regimes over the last 350 years thus indicates that they have come full circle and have been adapted to be democratic apparatus of economic growth and economic justice. It began with the Dutch rule treating water as a public commodity under complete government control. The British rule brought a complete change in the water rights regime by treating water as a private commodity and introducing riparianism. The Afrikaner nationalists again enforced government control on water use and treated water as a public commodity thus swinging the balance in favour of the dominus fluminis principle. The democratic government basically used a mix of both dominus fluminis and market-based principles to suit the democratic situation and to provide a balance between the societal need to provide water to all and the need to use this scarce resource efficiently. The principles of water demand management are used, so as not to sacrifice economic growth a sine qua non for increasing social welfare in the long run. A few important policy lessons can be learned from this analysis and are discussed below.

\section{Key policy lessons}

First, the analysis of the long history of water rights/laws in South Africa shows clearly that the political apparatus is most important in shaping the water rights structure. A democratic political structure promotes a fairer structure of water rights which are beneficial to all subjects. Colonial rules favoured a certain set of people and thus ignored the overall development of the country. Promotion of democratic regimes in the African continent will improve the overall water rights structure.

Second, since water is an economic good, its efficient use cannot be ignored if people want a sustainable supply of water under any type of political structure in the country. Equity or human rights issues related to water are important in Africa, yet this cannot be simply relegated to an issue of consumption alone. Water is an economically scarce resource and market principles cannot be underemphasised for sustainable development in African countries. The National Water Act in South Africa confirms this assertion by ensuring a framework that will work out a balance between property rights and human rights to water use. Since there are 3 legal forms of right to water: human right, contractual right, and property right (ODI, 2004), the contractual and property rights outweigh the human right in practice. The major problem arises in terms of willingness of the state to enforce the human rights dimension of water use. South African law has taken cognisance of this form and instituted mechanisms to effect this change, although they are not as successful as it was hoped they would be (Tewari, 2008).

Third, water use efficiency is to be enforced by devolving water management in the country at the catchment level. Catchment management agencies are statutory bodies which are responsible for:

- Development of a strategy in the catchment to meet the objectives of the Act

- Management of water resources and coordination of the water-related activities of water users and other water management institutions within the area.

This decentralisation is an important step in managing natural resources such as water and will certainly bring benefits in terms of increased efficiency and equitable distribution of water in the country (Ribot, 2002). The rest of the African continent can emulate some of these principles if it suitstheir needs.

Fourth, in terms of water rights theory, licensing water use is a new way of dispensing water in societies where the human rights form of water use is very critical due to constitutional 
and historical reasons. Many African countries show such symptoms. Licensing can be a noble innovation in the legal history. However, the efficacy of this method depends upon the institutional efficiency of the state.

\section{Acknowledgements}

The author is grateful to anonymous referees for making various suggestions. This version provides a detailed review of events in the South African history of water rights. The work heavily draws from Hall (1939, 1947, 1963), Hall and Fagan (1933), Hall and Burger (1974), DWAF's White Paper on a National Water Policy for South Africa, (DWAF, 1997) and National Water Resource Strategy (DWAF, 2004), Thompson et al. (2005), Thompson (2006) and Kidd (2009).

\section{References}

BENNET TW (1995) Human Rights and African Customary Law. Juta and Co, Cape Town.

BLACK P and FISHER BL (2001) Conservation of Water and Related Land Resources ( $3^{\text {rd }}$ edn.). Lewis Publishers, Bo Raton.

BRONSTEIN V (2002) Drowning in the hole of the doughnut: regulatory overbreadth, discretionary licensing and the rule of law. S. Afr. Law J. 119 (3) 469.

BURMAN SB (1973) Cape Policies Towards African Law in Cape Tribal Territories: 1872-1883. Ph.D. Thesis, University of Oxford.

CAPONERA DA (1998) The importance of water law and institutions for sustainable development. Working paper presented at the INBO workshop on Users' Participation in the Management and Funding of Business Organizations, International Conference on Water and Sustainable Development, 19-23 March, 1998, UNESCO, Paris.

DAVIS NN (1989) A History of Southern Africa. Longman, London.

DE WET (1959) One hundred years of water law. Acta Juridica 1959 31-35.

DE WET JC (1979) Opuscula Miscellanea. Butterworth Press, Durban.

DULY LC (1968) British Land Policy at the Cape, 1795-1844: A Study of Administration Procedures in the Empire. Duke University Press, Durham, N. C.

DWAF (DEPARTMENT OF WATER AFFAIRS AND FORESTRY, SOUTH AFRICA) (1986) Management of the Water Resources of the Republic of South Africa. Department of Water Affairs and Forestry, Pretoria.

DWAF (DEPARTMENT OF WATER AFFAIRS AND FORESTRY, SOUTH AFRICA) (1997) White Paper on a National Water Policy for South Africa.. Department of Water Affairs and Forestry, Pretoria.URL: www.dwaf.gov.za/documents/policies/nwpwp.pdf (Accessed 20 November 2007).

DWAF (DEPARTMENT OF WATER AFFAIRS AND FORESTRY, SOUTH AFRICA) (2004) National Water Resource Strategy. Department of Water Affairs and Forestry, Pretoria.URL: http://www.dwaf.gov.za/documents/policies/NWRS/deafault.htm (Accessed 20 November 2007).

GETZLER J (2004) A History of Water Rights at Common Law. Oxford University Press, London.

GUELKE L and SHELL R (1992) Landscape of conquest: frontier water alienation and Khoikhoi strategies of survival, 1652-1780. J. South. Afr. Stud. 18 (4) 803-824.

HALL CG and FAGAN H (1933) Water Rights in South Africa. Juta, Cape Town.

HALL CG (1939) The Origin and Development of Water Rights in South Africa. Oxford University Press, Oxford.

HALL CG (1947) Water Rights in South Africa (2 $2^{\text {nd }}$ edn.). Oxford University Press, Oxford.

HALL CG (1963) (ed.) Decisions of the Water Courts of the Union of South Africa: From August, 1921 to December, 1928 Inclusive. Juta, Johannesburg.

HALL CG and BURGER AP (1974) Hall on Water Rights in South Africa ( $4^{\text {th }}$ edn.). Juta, Cape Town.
HAMILTON HALL WM (1898) Report on Irrigation Legislation and Enterprise in American States. Australian Colonies and Several Countries of Europe as Applicable to the Cape Colony. G 45 to 98. WA Richards \& Sons, Government Printers, Cape Town.

HODGSON S (2006) Modern Water Rights: Theory and Practice. FAO, Rome, FAO Legislative Study 92. 116 pp.

HODSON TA (1997) South African Land Tenure, Past and Present: A Country Report, University of Maine. URL: http://www.spatial. maine.edu/-onsurd?landtenure/countryReport/southAfrica.html (Accessed 9 January 2008).

KIDD M (2009) The development of water law. In: Dellapenna JW and Gupta J (eds.) The Evolution of the Law and Politics of Water. Springer Netherlands, Dordrecht. 87-104.

LEE RW (1956) The Elements of Roman Law. Sweet and Maxwell, London.

LEWIS AD (1934) Water Law: Its Development in the Union of South Africa. Juta, Cape Town.

MILTON JRL (1995)() The history of water law, 1652-1912. In: Land and Agriculture Policy Centre, Submission to the Department of Water Affairs and Forestry (unpublished August, 1995).

MULLER M (2001) Transforming Water Law to Achieve South Africa's Development Vision: A Case Study in National Law. Speech delivered on 16 March 2001 by Mike Muller, DirectorGeneral, Department of Water Affairs and Forestry, South Africa. URL: www.dwaf.gov.za/communications (Accessed 19 February 2008).

MULLER M (2008) Personal communication. Visiting Adjunct Professor at the Graduate School of Public and Development Management, University of the Witwatersrand. 28 September, 2008.

NKOMAZANA F (1998) Livingstone's ideas of Christianity, commerce and civilization. Botswana J. Afr. Stud $12(1,2)$ 44-57.

NWA (1998) National Water Act (Act No. 36 of 1998). Government Gazette 398 (19182). 26 August 1998, Cape Town, South Africa.

NUNES KD (1975) Sources of public streams in modern South African law. Acta Juridica 1975 298-331.

ODI (OVERSEAS DEVELOPMENT INSTITUTE) (2004) Right to Water: Legal Forms, Political Channels. ODI Briefing Paper, July 2004. Overseas Development Institute, London,

RIBOT JC (2002) Democratic Decentralization of Natural Resources: Institutionalizing Popular Participation. World Resources Institute, Washington, DC.

RSA (REPUBLIC OF SOUTH AFRICA) (1996) The Constitution of the Republic of South Africa.

SANCID (SOUTH AFRICAN NATIONAL COMMITTEE ON IRRIGATION AND DRAINAGE ) (2009) Country Profile-South Africa. URL: http://www.icid.org/cp_Safrica.html (Accessed 20 May, 2009).

SCHWULST L (1995) Water meters: legal requirements for trade use water meters in South Africa. IMIESA 20 (9) 38-39.

STEIN R (2002) Water sector reform in Southern Africa: some case studies. In: Turton AR and R Henwood R (eds.) Hydropolitics in the Developing World: A Southern African Perspective. African Water Issues Research Unit, Pretoria. 113-123.

STEIN R (2005) Water law in a democratic South Africa: a country case study examining the introduction of a public rights system. Texas Law Rev. 83 (7) 2167-2183.

TEMPLE J (2005) Dual economy models: a primer for growth economists. The Manchester School 73 (4) 435-478.

TEWARI DD (2005) A brief historical analysis of water rights in South Africa. Water Int. 30 (4) 438-445.

TEWARI DD (2008) Engendering economic development through enforcement of justiciable human rights to water in South Africa. Paper presented at the $2^{\text {nd }}$ World Aqua Congress, 26-28 November, Delhi, India.

TEWARI DD and KUSHWAHA RL (2007) Socio-economics of groundwater management in Limpopo, South Africa: poverty reduction potential and resource management challenges. Water Int. 33 (1) 69-85.

THOMPSON H (2006) Water Law: A Practical Approach to Resource Management and the Provision of Services. Juta, Cape Town. 
THOMPSON H, STIMIE CM, RICHTERS E and PERRET S (2001) Policies, Legislation and Organizations Related to Water in South Africa with Special Reference to the Olifants River Basin. Working Paper No. 18 (South Africa Working Paper No. 7), International Water Management Institute, Colombo.

TLOU T, MOSAKA D, PERRET S, MULLINS D and WILLIAMS CJ (2006) Investigation of Different Farm Tenure Systems and Support Structures for Establishing Small-Scale Irrigation in Long Term Viable Conditions. WRC Report No. 1353/1/06, Water Research Commission, Pretoria, South Africa. 174 pp.

TURTON AR, MEISSNER R, MAMPANE PM and SEREMO O (2004) A Hydropolitical History of South Africa's International River Basins. WRC Report No. 1220/1/04. Water Research Commission, Pretoria, South Africa.

TURTON AR, SCHULTZ C, BUCKLE H, KGOMONGOE M, MALUGANI T and DRACKNER M (2006) Gold, scorched earth and water: the hydropolitics of Johannesburg. Water Resour. Dev. 22 (2) 313-335.

UYS M (1996) A Structural Analysis of the Water Allocation Mechanism of the Water Act 54 of 1956 in the Light of the Requirements of Competing Water User Sectors with Special
Reference to the Allocation of Water Rights for Ecobiotic Requirements and the Historical Development of the South African Water Law, Volume II. WRC Report No. 406/2/96. Water Research Commission, Pretoria, South Africa.

VAN DER MERWE F (2000) Registration and licensing of water-use: water feature. SA Irrig. 22 16-18.

VAN KOPPEN BCM (2005) The relevance of the histories of water laws in Europe and its former colonies for the rural poor today. Paper presented at the Workshop on African Water Laws, 26-28 January, 2005, Johannesburg, South Africa,

VOS WJ (1978) Elements of South African Water Law (2 $2^{\text {nd }}$ edn.) Juta, Cape Town

WATER ACT (1956) Water Act (Act No. 54 of 1956). Republic of South Africa.

WIEL SC (1909) Running water. Harv. Law Rev. 22 (3) 190-215.

WLRP (WATER LAW REVIEW PANEL) (1996) Fundamental Principles and Objectives for a New Water Law in South Africa. Report to the Minister of Water Affairs and Forestry of the Water Law Review Panel. January 1996, Pretoria.

WSA (1997). Water Services Act (Act No. 108 of 1997). Government Gazette 390 (18522). 19 December 1997. Republic of South Africa, Cape Town. 


\section{Appendix A}

\begin{tabular}{|c|c|}
\hline \multicolumn{2}{|r|}{$\begin{array}{c}\text { Table A.1 } \\
\text { Timeline of Water Rights in South Africa, } 1652 \text { to date }\end{array}$} \\
\hline 1652: & Arrival and establishment of Dutch Colony at the Cape of Good Hope. \\
\hline 1655: & $\begin{array}{l}\text { Van Riebeeck makes the } 1^{\text {st }} \text { act of State (by way of Placcaet) control over public streams to } \\
\text { prohibit upstream use of streams for washing persons and possessions. }\end{array}$ \\
\hline 1657: & Repetition of the General Placcaet (Proclamation) prohibiting upstream water pollution. \\
\hline 1661: & $\begin{array}{l}\text { Prohibition of use of upstream water by free burghers for irrigation and Company control of } \\
\text { river streams begins. }\end{array}$ \\
\hline 1685: & $\begin{array}{l}\text { Certain settlers were granted land ownership by the Dutch East India Company based on court } \\
\text { rulings. These owners were given control of any permanent water supply source that flowed } \\
\text { across their piece of land - which later became known as the riparian principle. }\end{array}$ \\
\hline 1761: & $\begin{array}{l}\text { Council of Policy resolution authorised the use of water of the Table Bay Valley streams for } \\
\text { irrigating gardens for } 4 \text { out of } 24 \text { hours. Also, the then governor of the Cape, Ryk Tulbagh, and } \\
\text { the Council of Policy considered the matter of water use by some riparian users from the stream } \\
\text { above the Company's mills and fined them, confirming the dominus fluminis status of the state. }\end{array}$ \\
\hline 1763: & Ackerman $v$ the Company \\
\hline 1774: & $\begin{array}{l}\text { The proposed arrangements of turns of water-leading for private owners was adjusted so that the } \\
\text { Company's gardens situated lower down the stream would not be deprived of a proper supply of } \\
\text { water. The dominus fluminis status of the state was forcibly applied from this year. }\end{array}$ \\
\hline 1787: & $\begin{array}{l}\text { In 1787, the Council appointed a committee to look into the grievances of all owners of gardens } \\
\text { in Table Bay Valley. The water leading time was extended to } 8 \text { hours out of } 24 \text { hours and a new } \\
\text { system of water distribution by turns was adopted. }\end{array}$ \\
\hline 1805: & Dutch Rule ended. \\
\hline 1806: & Cape finally occupied by the British. \\
\hline 1813: & $\begin{array}{l}\text { The } 2^{\text {nd }} \text { British Governor, Sir John Craddock, established a new land tenure policy which } \\
\text { practically disenabled the state as dominus fluminis in water rights. }\end{array}$ \\
\hline 1820: & $\begin{array}{l}\text { Beginning of preference of appointment to the Supreme Court Bench of lawyers trained either in } \\
\text { England or Scotland. }\end{array}$ \\
\hline 1827: & $\begin{array}{l}\text { The Landdrost and Heemraden were abolished and replaced by Magistrates with very limited } \\
\text { jurisdiction. }\end{array}$ \\
\hline 1828: & $\begin{array}{l}\text { Establishment of the Supreme Court, which was the only tribunal authorised to decide water } \\
\text { cases. }\end{array}$ \\
\hline 1856: & $\begin{array}{l}\text { The court case Retief } v \text { Louw marked a clear movement away from the state control of water- } \\
\text { courses. In this, case, Judge Bell ignored the dominus fluminis principle and used the Anglo- } \\
\text { American doctrine of riparian rights to decide on the case. After a gradual process beginning } \\
\text { with the } 1813 \text { new land policy, the state finally faded out as the dominius fluminis. }\end{array}$ \\
\hline 1869: & $\begin{array}{l}\text { Privy Council heard appeal from judgment in Silberbauer } v \text { Van Breda. The judgment concluded } \\
\text { that Roman-Dutch principle that owner has the absolute right to water rising on his land as per } \\
\text { Voet was not acceptable in the colony. }\end{array}$ \\
\hline 1873: & $\begin{array}{l}\text { Appointment of Sir Henry de Villiers as Chief Justice of the Cape Colony heralded a new era in } \\
\text { laying down the principle of riparianism in the colony. }\end{array}$ \\
\hline 1874: & $\begin{array}{l}\text { Beginning of a series of decisions by the Supreme Court, taking from the Roman Law the basic } \\
\text { idea that running streams are res publicae, adopted from the English and Scottish law princi- } \\
\text { ple that the riparian owners are entitled to the common use of water of a stream to which their } \\
\text { properties are contiguous. The case of Hough } v \text { Van der Merwe brought a landmark decision that } \\
\text { water from a non-perennial spring or source was part of a public stream if it had been flowing } \\
\text { down to, and was used commonly by, lower owners. }\end{array}$ \\
\hline 1886- & $\begin{array}{l}\text { Gold was discovered in the Johannesburg area and the Rand Water Board was established in } \\
1903 \text { to meet water demand in the greater Witwatersrand area. Many migrants were allowed to } \\
\text { settle in the mining town of Johannesburg. Legislation was later passed to allow for granting } \\
\text { water rights to mining operations with priority over other uses. }\end{array}$ \\
\hline
\end{tabular}




\begin{tabular}{|c|c|}
\hline 1894: & $\begin{array}{l}\text { The } 1^{\text {st }} \text { legislative step in the direction of providing substantive rules for the use of public water } \\
\text { was taken in the Transvaal under Law } 11 \text { of } 1894 \text {. However, these rules ignored the principle of } \\
\text { proportionate sharing amongst all the owners riparian to a stream, which the Cape courts had } \\
\text { laid down as a fundamental rule of common law. }\end{array}$ \\
\hline 1899: & $\begin{array}{l}\text { Act } 40 \text { of } 1899 \text { (Cape) provided the } 2^{\text {nd }} \text { step in the codification of the law of water rights by } \\
\text { creating water courts with jurisdiction to decide all disputes and claims as to water rights. }\end{array}$ \\
\hline 1906: & $\begin{array}{l}\text { Cape Parliament passed a comprehensive measure by which the existing law relating to the } \\
\text { use of the water of streams which were public at common law was effectively codified and the } \\
\text { principle of common use was extended to streams which had hitherto fallen outside the scope of } \\
\text { its operation. }\end{array}$ \\
\hline 1912: & Completion of the codification of the law of water rights for the Union of South Africa. \\
\hline $\begin{array}{l}\text { 1952- } \\
72:\end{array}$ & $\begin{array}{l}\text { A Commission of Inquiry into Water Matters was set up to report on the water needs of various } \\
\text { secondary water users as well as their effects on water availability. The Commission of Inquiry } \\
\text { was set up with pressure from the lobbying of the industrialists who had the support of mining } \\
\text { and commerce industries. The report of this Commission became the basis for the new Water } \\
\text { Act (No. } 54 \text { of 1956). This permitted the state to use the principle of government control areas } \\
\text { which was systematically extended to cover in some or other measure all sources of natural } \\
\text { water. The state was thus re-invested with dominus fluminis status for all practical purposes, } \\
\text { bearing in mind the increasing demand for water and fixed water supply. }\end{array}$ \\
\hline 1984: & $\begin{array}{l}\text { Water rights for the forestry sector controlled by an Act of Parliament after its identification as a } \\
\text { major water user with direct effect for downstream users. }\end{array}$ \\
\hline 1994: & $\begin{array}{l}\text { The democratic transition necessitated a water legislation rationalisation and amendment } \\
\text { process. Consultations that led to the writing of a new Water Act began. }\end{array}$ \\
\hline 1996: & $\begin{array}{l}\text { The Fundamental Principles and Objectives for a New Water Law in South Africa were } \\
\text { approved by the Cabinet. }\end{array}$ \\
\hline 1997/8: & The National Water Act and Water Services Act were passed and published. \\
\hline
\end{tabular}

